\title{
Populism and Environmental Performance
}

Tobias Böhmelt*

\begin{abstract}
This article examines the impact of populism on environmental politics, focusing on countries' outcome-level performance. I develop the argument that populist leadership likely undermines environmental quality. First, populist leaders tend to reject and refrain from implementing "green" policies as these are usually promoted by "corrupt elites." Second, populism erodes democratic institutions, thus offsetting a series of mechanisms that are related to better environmental outcomes. Empirically, I combine data from the Global Populism Database covering 66 countries and more than 200 executive leaders with information on environmental performance at the outcome level. The findings suggest that populist leadership is strongly linked to lower environmental performance - also when controlling for a series of alternative influences and distinguishing between left and rightwing populism. This research greatly adds to our understanding of the determinants of environmental policies, the role of regime type and ideology, and the literature on populism.
\end{abstract}

\section{Introduction}

The study of populism, its emergence, and consequences has become one of the most influential fields in the social sciences (e.g., Akkerman et al. 2014; Bos et al. 2013; Busby et al. 2019; de la Torre 2015; Caramani 2017; Hameleers et al. 2017; Hobolt 2016; Oliver and Rahn 2016; Rooduijn 2019; Rooduijn et al. 2016; Castanho Silva et al. 2018; 2020; Van Hauwaert et al. 2020; Wuttke et al. 2020). Commonly, populism is defined as "a thin-centered ideology that considers society to be ultimately separated into two homogeneous and antagonistic groups, the people and the corrupt elite, and which argues that politics should be an expression of the volonté générale (general will) of the people (Mudde 2004, 543)." Populism is thus not tied to specific ideological positions and there are both left-wing and right-wing movements (Rooduijn and Akkerman 2017; Otjes and Louwerse 2015; Akkerman et al. 2017; Huber and Ruth 2017; Huber and Schimpf 2017; Taggart 2002; Forchtner and Kølvraa 2015). Three main criteria constitute the core of its definition: anti-elitism, peoplecentrism, and a Manichean discourse that actively proclaims a moral struggle between "good people" and "the elite" (Hawkins 2003; Mudde 2004; Hawkins and Kaltwasser 2018; see also Canovan 1981; Huber and Schimpf 2015). Hence, populism essentially is anti-politics, claiming to pursue a new morale (Mudde and Kaltwasser 2012, 8) as it opposes the establishment and "corrupt elites" - the actors generally seen at the center of political decision-making and power (Hay and Stoker 2009; Huber 2020).

Populism influences political attitudes, behavior, and action in numerous ways (Doyle 2011; Panizza 2000; Roberts 2007; Huber 2020). For instance, there is work on immigration policies (Akkerman 2012), polarization (Rooduijn et al. 2016), or liberal democracy (Huber and Schimpf 2015). Environmental politics also increasingly acknowledges the power of

\footnotetext{
* Tobias Böhmelt: University of Essex, Department of Government, Wivenhoe Park, Colchester CO43SQ, UK, Tel: +44(0) 120687 2288, Email: tbohmelt@essex.ac.uk. Supplemental material, the data set, and the replication files referred to in the text can be obtained from the author upon request. I thank the editors of Global Environmental Politics, Steven Bernstein, Matthew Hoffmann, and Erika Weinthal, the managing editor, Susan Altman, and the anonymous reviewers for their support and feedback.
} 
populism. Addressing environmental problems, including climate change as one of the most pressing policy issues of our time, is a key challenge. Effectively improving environmental quality needs significant and costly changes in the behavior of all actors - even down to the individual. The technical nature of such issues and their solutions, however, make environmental politics an easy target for populists (Oliver and Rahn 2016). Existing research on populism and the environment is dominated by micro-level analysis on public opinion, attitudes, and populist views of individuals. For instance, Huber et al. (2020) examine how populist attitudes are related to views on climate change mitigation (also Huber 2020). And Lockwood (2008) provides a theoretical framework that links populism and attitudes toward the environment: according to him, populists oppose pro-environmental ideas as corresponding policies threaten job security in low-skilled manufacturing and populism directly appeals to audiences here. Right-wing populism, in particular, is against environmental policies as it assumes more conservative, nationalist values, which see crosscountry responses to environmental threats potentially compromising state sovereignty. What is missing in this literature is a large-scale, comparative, and systematic assessment of how populism can influence environmental politics.

Using a uniquely compiled data set, I address this shortcoming both theoretically and empirically as I study the impact of populist leadership ${ }^{1}$ on environmental performance at the outcome level. I develop an argument via two mechanisms. On one hand, populism, in light of its anti-elitist approach, portrays decision-makers, public institutions, scientists, or activists promoting environmental-friendly policies as "detached" and "corrupt" elites failing to meet the needs of the general will. Environmental politics tend to be rather abstract and technical, and the "populist backlash against globalization" (Huber 2020, 2; Norris and Inglehart 2018) focuses on precisely this. In turn, environmental politics is simply diminished as an elite project (Huber 2020), and populist leaders likely reject and refrain from implementing environmental-friendly policies as these are usually promoted by those that populist leaders have campaigned against in the last election. On the other hand, populism erodes democratic institutions, thus offsetting a series of mechanisms that are related to better environmental outcomes. Empirically, I combine data from the Global Populism Database (Hawkins et al. 2019) with information on environmental outcomes and find that populist leadership is strongly linked to lower environmental performance.

Several important policy implications follow from this research. Most crucially, this study adds to the existent work reporting that populism may indeed be associated with normatively negative policy outcomes. Recently, scholars suggest that populist leaders are a liability in the fight against COVID- $19^{2}$ and I show that this also applies in another, public-good related context: the environment. In order to effectively fight climate change and to improve environmental quality, voting populists into power is an ill-advised choice against the background of my research. And, indeed, anecdotal evidence supports this conclusion: the outgoing US President Donald Trump is widely seen as a populist (Bonikowski 2019). The Washington Post estimates that his administration "rolled back more than 125 environmental safeguards," 3 while the New York Times concludes that one of Trump's legacies will be that "much of the damage to the climate [caused by his administration] cannot be reversed." $\mathrm{By}$ implication, this work informs voters about the success and effectiveness of populist

\footnotetext{
${ }^{1}$ Specifically, I focus on political executives. This does not imply, however, that junior coalition partners or pressure groups at the grass-roots, e.g., Extinction Rebellion, cannot be "populists" or that they are without influence. I return to this issue in the conclusion.

${ }^{2}$ See online at: https://theconversation.com/are-populist-leaders-a-liability-during-covid-19-135431.

${ }^{3}$ See online at: https://tinyurl.com/yy95ymoa.

${ }^{4}$ See online at: https://www.nytimes.com/2020/11/09/climate/trump-legacy-climate-change.html.
} 
leadership: while populists may claim to represent the general will and promise policies that are popular among large segments of the electorate, they are ultimately unlikely to address the most pressing policy issues of our time in a successful manner, including climate change and (global) environmental problems.

This research further enhances our understanding of the determinants of environmental policies, the role of regime type and ideology, as well as populism and its consequences. First, there is a vast amount of studies focusing on the determinants of environmental performance, which improve our knowledge of what factors may facilitate or hamper environmentalfriendly outcomes. However, the influence of populism has been overlooked so far, although - as I demonstrate below - its impact is both significant and substantial. I thus broaden the scope of the literature by introducing populism to the study of environmental performance at the macro level. Second, and related to the first point, there are plenty of works on the link between regime type and environmental performance. Although some suggest that more democratic regimes or more left-wing ideologies are "better" for the environment, results are generally largely mixed and do depend on contextual conditions. This ambiguity about the influences stemming from regime type and political ideology may suggest that there is a missing component, which has not been fully integrated in existing theoretical and empirical models. I contend that populism could be this missing aspect, also as is orthogonal to ideology and "traditional" forms of government. Third, while there is research on the consequences of populism and populist attitudes, including on environmental public opinion, thus far we lack a comprehensive and systematic analysis of how populism affects environmental performance at the macro level. I provide such an assessment, thereby contributing to the emerging field of studies focusing on the impact of populism.

\section{Regime Type, Ideology, Populism, and the Environment - A Brief Review}

This research builds upon and extends previous works on regime type, ideology, and - more recently - populism and environmental politics. In the following, I briefly discuss each of these strands, thereby highlighting where and how my study contributes to the literature. First, there are several works focusing on regime type and environmental performance. On one hand, some scholars suggest that democracies more strongly promote green policies and are linked to better environmental performance (Congleton 1992; Payne 1995; Li and Reuveny 2006; Bernauer et al. 2013). The mechanisms behind this relationship argue that democracy is characterized by more civil liberties (Payne 1995), which allow citizens to be more informed about environmental problems and governmental policies. Second, civil liberties also comprise opportunities to express opinions and organize movements to lobby executives. Ultimately, domestic audiences in democracies can impose higher audience costs on leaders and are able to remove them from power more easily than in non-democratic polities.

Consistent with this argument, the "median voter" is decisive for the provision of public goods in democracies (Congleton 1992; McGuire and Olson 1996; Niskanen 1997; Lake and Baum 2001). Democratic political leaders want to satisfy their constituencies' policy demands as this is necessary for obtaining or retaining office (Downs 1957). Bueno de Mesquita et al. (2013) argue here that democracies outperform non-democratic regimes in the provision of public goods as this is a more cost-efficient way to satisfy the electorate in this context. The median voter in a democracy "incurs lower marginal costs of public goods provision, relative to the average member of the economic and political elite in a non-democracy" (Bernauer et al. 2013, 95). In turn, democratic governments have strong incentives to invest in public goods. In line with this, Anderson et al. (2017) report that public opinion shapes 
environmental policies: democratic politicians react to what the public wants due to the central incentive to stay in power (also Page and Shapiro 1983; Dahl 1956; Downs 1957; Arrow 1963). In other words, democratic political leaders are responsive to domestic audiences; they resort to the provision of public goods to ensure political support and survival in office. The environment may not be an exception here and democratic governments then invest more in the public good of "environmental quality" (see also Bernauer and Koubi 2009; Dasgupta and De Cian 2018).

There are several studies that focus on governments' ideological positions and environmental politics. Ideology is strictly speaking independent of regime type as such, although empirical analyses naturally focus on democracies when examining the influence of right-wing or leftwing ideologies of political parties and governments. Early evidence points toward a positive impact of more left-wing executives and environmental performance both at the output and the outcome level (Tobin 2017; Chang, Lee, and Berdiev 2015; Jahn 2016). While the specific mechanisms for this relationship may vary, arguments converge on "equality, distributional concerns, and market skepticism" (Neumayer 2003, 203) as being core aspects that define left-wing political ideology, which are also likely conducive to environmental quality and policies promoting this. For example, Neumayer $(2003 ; 2004)$ argues that poorer individuals and the working class are affected the most by environmental problems. Leftist parties, once in power, seek to address this with adequate policies, which eventually promote environmental quality.

That said, neither the democracy-environment link nor the positive association between leftwing ideology and environmental performance are robust. In fact, empirical results are mixed, and ambiguity persists about how the form of government and ideology, respectively, are related to environmental performance in a consistent fashion. Ward (2008), for example, shows that democracies may have a better environmental output than other forms of government, but their outcome performance depends on the specific indicator examined. In terms of ideology, the positive effect of left-wing positions is largely driven by the actual proenvironmental views of parties and governments - but not leftist ideologies per se (Jahn 1998; Knill, Debus, and Heichel 2010; Ward and Cao 2012, Schulze 2014. Leinaweaver and Thomson 2016). There is also some evidence linking more right-wing ideologies to environmental quality as right-wing parties have begun to take over some of the more traditional policy positions of green parties (Garmann 2014). Gassebner et al. (2011), one of the most comprehensive reviews in this literature, conclude that there is no robust direct effect of left-wing ideology on environmental outcomes.

A number of works have emerged that examine populism in the context of environmental politics (Dasgupta and De Cian 2018; Beeson 2019). Huber (2020), for instance, makes use of the British Election Study and identifies a strong link between populist views and climate skepticism. Lockwood (2018) proposes a theoretical framework linking populist attitudes and environmental politics. On one hand, this framework comprises a structuralist explanation, which is based on the economic and political marginalization of the society's globalization losers. On the other hand, there is an ideological explanation highlighting that right-wing populists see climate action as a project of a "cosmopolitan elite," going against the interests of "the people." Lockwood's work, though inspiring in many ways, is only theoretical and does not empirically test its propositions. Huber et al. (2020) fielded surveys in the US and they demonstrate that populism affects people's climate attitudes - the more populist one's views, the more skeptic they are of policies fighting climate change. The main argument of this research is based on the "chain of delegation" as the core of populist criticism: "populists tend to claim that elites are not responsive to citizens' needs and preferences and rather follow 
their own interests. Thus, the central actors in policy making, 'the people,' are mostly left out of the process" (Huber et al. 2020, 5). This degree of responsiveness, and especially the lack thereof, shapes individuals' support for climate policies. Huber et al. (2020) also report that populism moderates the impact of partisanship.

In sum, this overview highlights several limitations, which this study seeks to address. First, my discussion of two important strands in the literature - one on democracy and environmental politics and a second focusing on ideology - highlights that neither forms of government nor specific ideologies are robustly and consistently linked to environmental performance. Some element is missing in these debates and populism may well be this overlooked component as it is orthogonal to ideology and regime type. When considering populism in our study of environmental performance, therefore, we may shed light on persistent inconsistencies in empirical patterns and greatly add to our understanding of the drivers behind environmental quality. Second, there are important theoretical works and micro-level evidence on populism and environmental public opinion, but we lack a largescale, comparative, and systematic assessment of how populism can influence environmental performance.

\section{Populist Leaders and Environmental Outcomes - Theory}

The argument I develop is based on the definition of populism introduced above. In addition, due to my focus on political leaders, I assume that state executives have the key incentive to stay in power once office is assumed (Huber and Schmipf 2015). That is, populist leaders will seek to please the domestic audience for increasing the chances of re-election, also by seeking to mobilize "groups outside the system and attach new weight to their problems and particular issues" (Huber and Schmipf 2015, 3; Mudde and Kaltwasser 2012, 21). Against the background of these assumptions, I contend that populism likely has a detrimental impact on environmental quality.

\section{Environmental Policies and "Corrupt Elites"}

The first theoretical mechanism linking populist leadership to states' environmental performance is based on the abstract nature of environmental politics (Huber 2020). The drivers behind environmental problems as well as the consequences of environmental degradation are usually rather complex. Easy solutions to such problems are oftentimes not given. While it nevertheless remains vital that actors down to the individual alter their behavior, convincing them to do so is challenging if problems are abstract to begin with and solutions neither straightforward nor simple (Spence et al. 2012). Weber (2016) stresses here that this increases the social distance between ordinary citizens and environmental politics. Moreover, most environmental problems are of a transnational nature, requiring responses across borders from more than one nation state at a time. Hence, coordinated efforts are discussed in international negotiations, regularly without the direct involvement of domestic audiences and interest groups, which further detaches environmental problem-solving from the "ordinary citizen."

It is because of this complex and transnational nature that populists portray environmental politics as elite-driven, distant from the will of the people and "ordinary citizens' needs" (Huber 2020), and then oppose solutions to environmental degradation. By the same token, Huber $(2020,6)$ claims that environmental politics is only "of interest to richer and bettereducated citizens, and is a prime example of post-materialist issues" (see also Morrison and 
Dunlap 1986; Freudenberg and Steinsapir 1991; Inglehart 1995; Wetts 2020). Lockwood (2018) contends as well that people tend to see environmental politics more like an elitedriven and cosmopolitan issue area due to its more transnational nature. In turn, the general will is less concerned about or be able to influence environmental decision-making. This leads to a lack of responsiveness between elites and citizens' demands, which populists exploit by claiming to be the only genuine representative of the people (Huber 2020; Huber et al. 2020; Caramani 2017). Busby et al. (2019) refer to this as "dispositional blame attribution." This means that, as Huber et al. $(2020,2)$ conclude, "populist individuals are more likely to oppose the central actors involved in top-down climate policy (namely, the political elites that adopt climate policies) and are likely to reject climate-change-related mitigation policies proposed by the same actors."

Ultimately, the complexity surrounding environmental politics, a significant amount of uncertainty about its long-term implications (Spence et al. 2012; Weber 2016), as well as its transnational nature induce that populism frequently displays the environment as a top-down issue; and detached and corrupt elites who do not take the interests of the general will into account impose it (Castanho Silva et al. 2018; 2020; Hornsey et al. 2018). Populist attitudes thus tend to be more environmental-skeptic and opposed to protecting environmental quality. As Huber et al. $(2020,3)$ emphasize, the "antagonism between a good public and an evil elite represents a deeply populist claim" (also Hawkins and Kaltwasser 2018). Interestingly, populists reject not so much the environmental issue as such, but the fact that - as stressed by the complex and transnational character of environmental politics - these policies are pursued and implemented by elites who merely seek to further their own interests and not the general will of the people (Morrison and Dunlap 1986; Wetts 2020). The implication for populist leaders is then straightforward: once in power, they are unlikely to implement policies they campaigned against in the last election and doing so successfully as they have just gained office. In fact, pursuing such policies would decrease populist leaders' chances of staying in office. In the end, those elites and their policies are the main opponents for populists - and environmental policies are not an exception. Populist leaders are thus unlikely to engage in pro-environmental legislative action; in fact, they may even promote policies that openly go against environmental protection. Consider, for example, Brazil's President, Jair Bolsonaro, commonly portrayed as a right-wing populist, who "worked relentlessly and unapologetically to roll back enforcement of Brazil's once-strict environmental protections" once in power. In the end, a country's environmental performance should decrease.

\section{Populism and Undermining Institutions}

As discussed above, the empirical evidence for a robust link between democracy and environmental performance is mixed. However, when assuming a more disaggregated view, there are some, predominantly democratic, institutions that are commonly found to be conducive to environmental protection and quality: checks and balances as well as the process of finding a compromise in legislative action. First, political constraints or checks and balances pertain to institutional factors or actors in the political system that can prevent a choice from being made, i.e., a change from the status quo is averted and only the consent of the veto player can alter this (Tsebelis 1995; 1999). Second, compromise or a more inclusive political system is defined by "the proportion of the population entitled to participate on a more or less equal plane in controlling and contesting the conduct of the government" (Dahl

\footnotetext{
${ }^{5}$ See online at: https://www.nytimes.com/2019/08/27/world/americas/bolsonaro-brazil-environment.html.
} 
1971, 4). Both of these features may, at first, seem more like an obstacle to decision-making, including environmental politics, and thus a challenge for improving environmental performance.

However, more inclusive political systems in which all citizens can participate in environmental decision-making reaching compromise to enact policies are increasingly seen as a necessary condition for achieving sustainability (Böhmelt et al. 2016). While decisionmaking may take more time, inclusiveness and compromise allow environmentally aware citizens to channel their demands effectively, and they ensure that even ordinary citizens are being heard (Böhmelt et al. 2016, 1272-1273). Therefore, inclusiveness and compromise are key factors for achieving better environmental outcomes. A similar pattern is given for veto players and political constraints: while more checks and balances make "it difficult to implement far-reaching, but probably most effective climate change policies," systems characterized by more political constraints produce "politics of small steps that are supported by a broad political elite" (Stadelmann-Steffen 2011, 485; also Poloni-Staudinger 2008). Conversely, with more political constraints in place, it is equally difficult to implement antienvironmental policies that would lower environmental quality (Cao and Prakash 2012).

Populist leadership, however, tends to undermine and erode both checks and balances as well as the principle of inclusiveness and compromise. Mainly driven by what Huber and Schimpf $(2015,4$.) call an "anything goes mentality" (Hawkins 2003; Mudde 2004; Hawkins and Kaltwasser 2018; see also Canovan 1981; Huber and Schimpf 2015), populist leaders capitalize on the power they received from the popular sovereign and, once in office, seek to dismantle those institutions they perceive as dysfunctional - also because these institutions and processes are associated with the "corrupt elites" previously in power (Hawkins 2003). In turn, "populist leaders' own assessment of the volonté générale becomes their prevailing point of reference for decision making" (Huber and Schimpf 2015,4). Yet, as political constraints constitute an obstacle toward this, populist leaders will circumvent or remove them altogether. That is, having gained power based on the claim to represent the true political will and having removed the "corrupt elite" in the moral struggle between them and the populists' "good people," populist leaders may "change institutions as they see fit" (Huber and Schimpf 2015, 4).

What is more, this process goes hand in hand with a systematic exclusion of particular groups from decision-making, thus undermining compromise and inclusiveness. This is due to the moralization of politics, a key consequence of the Manichean discourse vested in populism (Hawkins 2003; Mudde 2004; Hawkins and Kaltwasser 2018; see also Canovan 1981; Huber and Schimpf 2015). Mudde and Kaltwasser $(2012,24)$ summarize accordingly that "populism in power leads to polarization and consequently defensive measures from the government." Hence, despite the claim to represent the general will of the citizenry, large segments of the society are no longer part of the political decision-making process - compromise may no longer be possible or allowed for at all. Eventually, this second mechanism points into the same direction as the first one: environmental performance will decrease due to populist leadership as this undermines the (largely democratic) institutions of checks and balances as well as inclusiveness and compromise. 


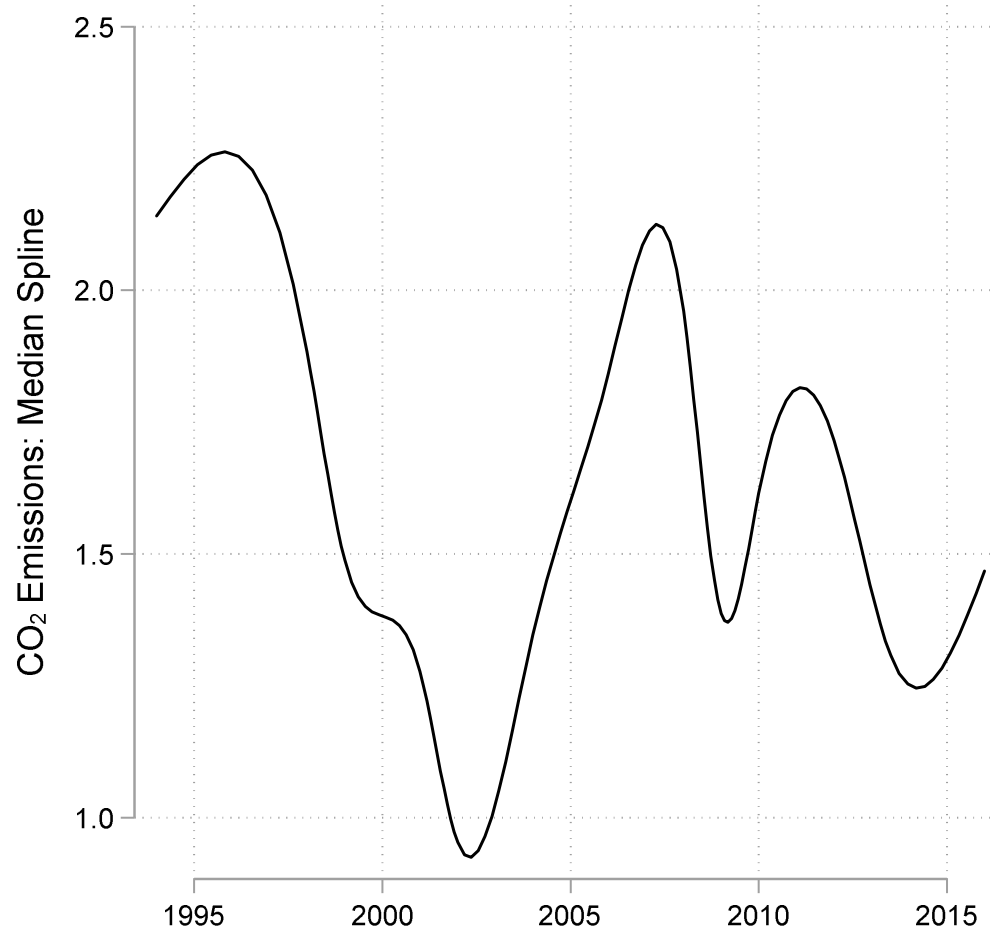

\section{Figure 1.}

$\mathrm{CO}_{2}$ Emissions per capita - Median Spline

Note: Graph prepared by author; figure shows distribution of outcome variable (metric tons per capita) across all countries and years in the sample.

\section{Research Design}

\section{Dependent Variable and Methodology}

I combine data on environmental outcomes with information on populist leadership. The latter is based on the Global Populism Database (GPD; Hawkins et al. 2019), and the spatiotemporal coverage of these data drive the unit of analysis, countries, and years covered in my analysis. Specifically, the GPD focuses on state executives and heads of government, coding for each of their terms in office their degree of populism (defined below). I employ the leader term as the unit of analysis, e.g., there are two entries for Barack Obama in the data set (20092013 ; 2013-2016). After accounting for missing values, I cover 66 countries and around 200 executive leaders (depending on model specifications) between 1994 and 2016.

The dependent variable of my analysis focuses on environmental performance at the outcome level. I employ per-capita $\mathrm{CO}_{2}$ emissions for the analyses presented below. While no single measure is ideal for all purposes, emissions per capita are extensively used in the literature as a proxy for environmental quality (e.g., Bernauer and Koubi 2009; Spilker 2012; Bernauer and Böhmelt 2013), also because of its wide spatio-temporal coverage. This research design choice is also justified from a substantive point of view as $\mathrm{CO}_{2}$ emissions constitute the major contributing factor of climate change and, in the long run, "the aim must be to reduce all countries' absolute level of emissions" (Böhmelt et al. 2018, 438). Moreover, $\mathrm{CO}_{2}$ emissions per capita meet the essential criteria for any environmental-quality indicator, namely they are produced by human activity, they can be subject to government regulations, they have 
available abatement technologies for implementation of the regulations, and data are available for a large set of countries (Bernauer and Koubi 2009, 1358.). To this end, I rely on the Carbon Dioxide Information Analysis Center of the Oak Ridge National Laboratory. Their data are available from the World Bank Development Indicators, with carbon dioxide emissions defined as those stemming from the burning of fossil fuels and the manufacture of cement, including emissions produced during the consumption of solid, liquid, and gas fuels and gas flaring. The final outcome variable captures emissions in metric tons per capita. Additional analyses in the appendix rely on alternative dependent variables in the form of an efficiency measure, a policy output measure, and a measure of ecological footprint.

Figure 1 depicts the development of $\mathrm{CO}_{2}$ emissions across all sample countries in my observation period as a median spline. A closer inspection at the underlying data reveals that there is low within country variation for some states. I address concerns related to this in the appendix by jackknifing the sample. Given $\mathrm{CO}_{2}$ emissions as my dependent variable, I employ multi-level linear regression models that comprise fixed effects for years and random intercepts for leaders. This ensures that I control for any unobserved unit-level effects as well as temporal shocks. In the appendix, I consider modifications to this estimation strategy as I look at a temporally lagged dependent variable or panel-corrected standard-errors models.

\section{Explanatory Variables}

The main explanatory variable, Populism Score, is taken from the GPD (Hawkins et al. 2019). The basic idea behind the GPD is to code populist discourse for political leaders using textual analysis of political speeches. The project, according to its codebook, "applies a technique known as holistic grading which was designed by educational psychologists to measure diffuse, latent aspects of texts such as tone, style, and quality of argument. The technique [...] has coders apply an integer grade scale and a rubric to identify rough attributes of texts at each grade." Furthermore, "texts are initially assigned one of three scores: (2) A speech in this category is extremely populist and comes very close to the ideal populist discourse. Specifically, the speech expresses all or nearly all of the elements of ideal populist discourse and has few elements that would be considered non-populist; (1) a speech in this category includes strong, clearly populist elements but either does not use them consistently or tempers them by including non-populist elements. Thus, the discourse may have a romanticized notion of the people and the idea of a unified popular will (indeed, it must in order to be considered populist), but it avoids bellicose language or references to cosmic proportions or any particular enemy; and (0) a speech in this category uses few if any populist elements. Note that even if a speech expresses a Manichean worldview, it is not considered populist if it lacks some notion of a popular will."

The sample of texts is a quota sample consisting of four speeches for each term in office: a campaign speech (usually the closing or announcement speech), a ribbon-cutting speech (marking a commemorative event with a small, domestic audience), an international speech (given before an audience of foreign nationals outside the country), and a famous speech (one widely circulated that represents the leader at his or her best). My final variable, Populism Score, is the average populism value for each leader term across the four speeches coded. In total, this variable covers 275 leader terms, has an average value of 0.342 , and ranges in 0 1.92.

For the control variables, I follow existing research on the determinants of environmental quality. First, I consider population, unemployment, and GDP per capita, which are all taken from the World Bank Development Indicators. For population, I rely on a country's midyear 
total population (log-transformed), which counts all residents regardless of legal status or citizenship (except for refugees not permanently settled). Unemployment is also logtransformed and refers to the share of the labor force that is without work but available for and seeking employment. Finally, the log-transformed GDP per capita (in current US Dollars) is defined as the gross domestic product divided by midyear population. GDP is the sum of gross value added by all resident producers in the economy plus any product taxes and minus any subsidies not included in the value of the products.

Second, I control for regime type and state capacity. The former is based on the polity 2 score from the Polity IV data set (Marshall et al. 2019). This variable ranges between -10 and +10 capturing perfect autocracies (minimum value) up to perfect democracies (maximum value). Controlling for regime type addresses those studies arguing for a relationship between forms of government and environmental performance. Recall, however, that my populism variable captures populism across the entire spectrum, i.e., left-right ideologies or democracies and autocracies. The state capacity control is taken from the World Bank's Worldwide Governance Indicators. It captures perceptions of the quality of public services, the quality of the civil service and the degree of its independence from political pressures, the quality of policy formulation and implementation, and the credibility of the government's commitment to such policies. Larger values pertain to higher governmental effectiveness. Controlling for state capacity addresses the alternative mechanism that a high-quality bureaucracy, even with a highly populist leader, may ensure the effective implementation of existing rules and regulations, including environmental laws that promote environmental quality.

Third, I incorporate two final controls pertaining to industrial output and a state's integration into the global system, respectively. On one hand, industrial output is based on manufacturing, value added, as a percentage of GDP. Value added is the net output of a sector after adding up all outputs and subtracting intermediate inputs. It is calculated without making deductions for depreciation of fabricated assets or depletion and degradation of natural resources. This variable thus captures how "industry-heavy" a state's economy is, with higher values standing for a larger manufacturing share and probably less environmental quality. On the other hand, domestic pollution is likely influenced as well by how integrated a country is in the international system. I use the globalization score from Dreher's (2006) Globalization Index.

\section{Empirical Findings}

Table 1 summarizes the main models: Model 1 is a standard model of environmental quality with $\mathrm{CO}_{2}$ Emissions as the dependent variable and the controls introduced above as explanatory variables. In Model 2, I add Populism Score but do not alter other specifications. In Model 3, I present a more parsimonious version of Model 2 as I only focus on the main explanatory variable and the most prominent controls used in the literature. All models comprise fixed effects for years and random intercepts for leaders, while the standard errors are also clustered at this latter level. The table entries are coefficients, which can be interpreted directly as marginal effects for a log-transformed outcome variable. To facilitate interpretation, I have calculated the predicted values of the outcome variable given the values of Populism Score while holding all other variables constant at their respective means.

Table 1. 
Results from Mixed-Effects Regression

\begin{tabular}{llll}
\hline & Model 1 & Model 2 & Model 3 \\
\hline Populism Score & & 0.112 & 0.127 \\
& & $(0.040)^{* * *}$ & $(0.043)^{* * *}$ \\
Population (ln) & 0.106 & 0.101 & 0.071 \\
& $(0.029)^{* * *}$ & $(0.029)^{* * *}$ & $(0.031)^{* * *}$ \\
GDP per capita (ln) & 0.487 & 0.484 & 0.554 \\
& $(0.059)^{* * *}$ & $(0.057)^{* * *}$ & $(0.033)^{* * *}$ \\
State Capacity & -0.251 & -0.209 & \\
& $(0.067)^{* * *}$ & $(0.067)^{* * *}$ \\
Unemployment (ln) & 0.142 & 0.138 \\
& $(0.041)^{* * *}$ & $(0.040)^{* * *}$ \\
Manufacturing & -0.004 & -0.005 & \\
& $(0.008)$ & $(0.008)$ & \\
Globalization & 0.036 & 0.036 & \\
& $(0.008)^{* * *}$ & $(0.008)^{* * *}$ \\
Democracy & -0.021 & -0.019 & -0.002 \\
Constant & $(0.010)^{* *}$ & $(0.011)^{*}$ & $(0.010)$ \\
& -6.372 & -6.342 & -4.065 \\
N & $(0.721)^{* * *}$ & $(0.702)^{* * *}$ & $(0.516)^{* * *}$ \\
Log Pseudolikelihood & 194 & 193 & 205 \\
Random Intercept & -61.409 & -56.381 & -80.281 \\
Time Fixed Effects & Yes & Yes & Yes \\
\hline
\end{tabular}

Note: Standard errors clustered on leaders in parentheses; * significant at $10 \%$; ** significant at $5 \%$; *** significant at $1 \%$ (two-tailed).

I find strong and robust support for my theoretical expectations: populism likely harms the environment in that more populist leaders are more strongly associated with lower environmental quality. The core item Populism Score is positively signed in Models 2-3 and statistically significant, which suggests that there is a correlation between more $\mathrm{CO}_{2}$ emissions and populism in the expected direction. Substantively, the coefficients emphasize that a one-unit increase in Populism Score leads to a rise in per-capita carbon emissions of 12.9 (Model 2) to 13.6 percent (Model 3). In other words, the main variable's impact is not only significantly relevant, but also substantively important.
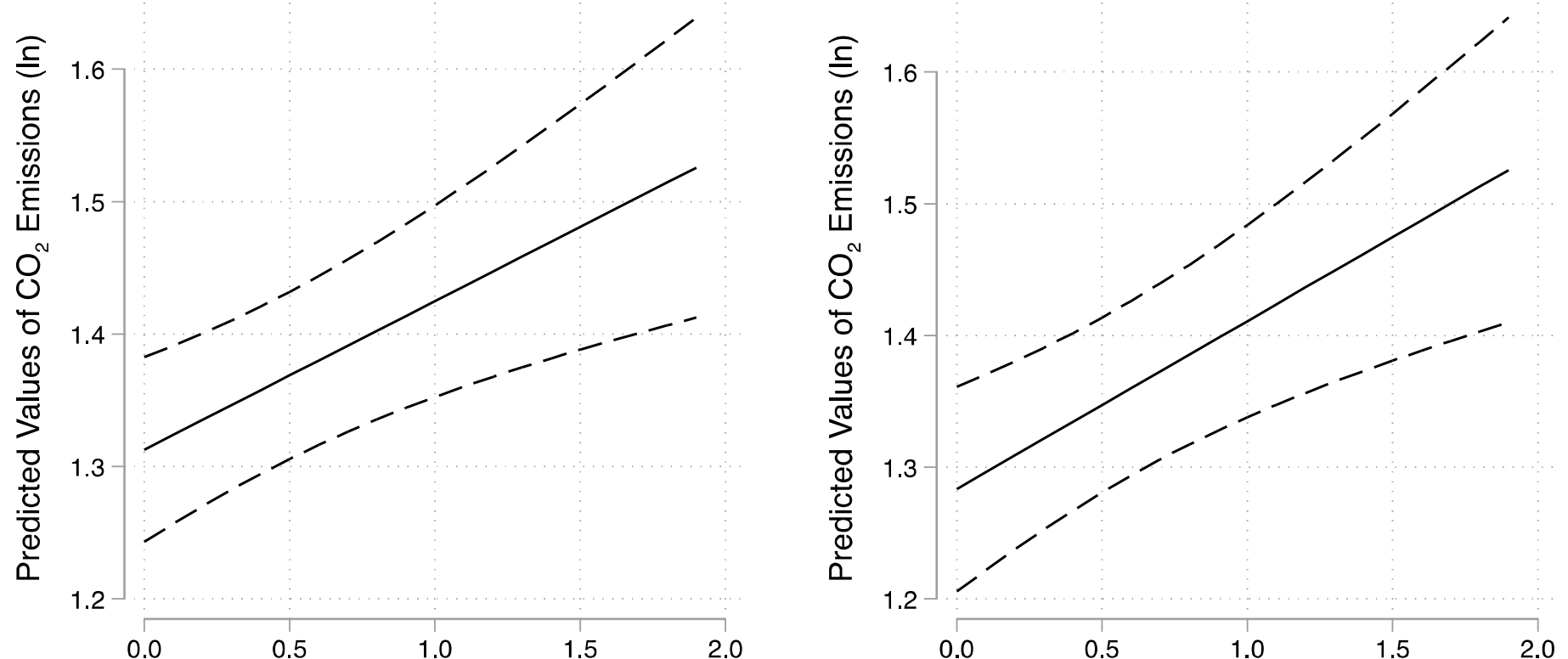


\section{Figure 2.}

Effect of Populism on Environmental Outcomes

Note: Graph prepared by author; dashed lines indicate the $90 \%$ confidence interval.

Figure 2 illustrates this as I plot predicted values of $\mathrm{CO}_{2}$ Emissions for Populism Score (holding all other variables constant at their means). Non-populist leaders are linked to percapita emissions of around 1.3, which translates into 3.67 metric tons per capita. Moving to a value of 1 for Populism Score, the predicted value of the outcome is 4.06 metric tons per capita and moving to the maximum of Populism Score is linked to 4.48 metric tons of carbon dioxide emissions per capita. Linking these results back to the theory, there is indeed systematic, cross-country evidence that populism induces lower environmental performance.

The control variables largely show expected effects, but some of those merit further attention. First, larger states, economically stronger ones, and higher rates of unemployment are consistently associated with more carbon emissions, i.e., more environmentally detrimental outcomes. The marginal effect of GDP per capita (ln) is, in fact, one of the largest ones across the model estimations, which mirrors earlier findings in the literature. Also, countries more strongly embedded in the international system tend to emit more $\mathrm{CO}_{2}$. A one-unit increase in Globalization leads to an emissions rise of about 3.7 percent. The variable Manufacturing does not achieve conventional levels of statistical significance in any model, though. Finally, State Capacity and Democracy reveal some interesting findings in the context of populism. On one hand, the negative and significant estimate for State Capacity demonstrates that a high-quality bureaucracy is indeed "good" for the environment. Most importantly, though, adding this variable next to Populism Score in the models does not render the latter insignificant. This emphasizes that there is a genuine effect stemming from populism.

Table 2.

The Moderating Effect of Political Ideology - Results from Mixed-Effects Regression

\begin{tabular}{lcc}
\hline & Model 4 & Model 5 \\
\hline Populism Score & 0.135 & 0.138 \\
& $(0.044)^{* * *}$ & $(0.075)^{*}$ \\
Left-Wing & 0.134 & $0.178^{*}$ \\
& $(0.089)$ & $(0.103)$ \\
Left-Wing * Populism Score & & -0.079 \\
& & $(0.099)$ \\
Liberals & $0.158^{*}$ & 0.126 \\
& $(0.091)$ & $(0.107)$ \\
Liberals $*$ Populism Score & & 0.024 \\
& & $(0.114)$ \\
Population $(\ln )$ & 0.070 & 0.071 \\
& $(0.031)^{* *}$ & $(0.031)^{* *}$ \\
GDP per capita $(\ln )$ & 0.559 & 0.551
\end{tabular}




\begin{tabular}{lll} 
& $(0.032)^{* * *}$ & $(0.032)^{* * *}$ \\
Democracy & -0.001 & -0.001 \\
Constant & $(0.010)$ & $(0.009)$ \\
& -4.254 & -4.228 \\
& $(0.523)^{* * *}$ & $(0.520)^{* * *}$ \\
\hline$N$ & 205 & 205 \\
Log Pseudolikelihood & -78.754 & -78.182 \\
Random Intercept & Yes & Yes \\
Time Fixed Effects & Yes & Yes \\
\hline
\end{tabular}

Note: Standard errors clustered on leaders in parentheses; right-wing ideology left out as baseline category; * significant at $10 \%$; ** significant at $5 \%$; ** significant at $1 \%$ (two-tailed).

On the other hand, the statistical significance of Democracy depends on specifications, although it is consistently negatively signed in Table 1 . While it is significant in Models 1-2 only, the overall pattern suggests that more democratic regimes tend to perform better environmentally. Again, including Populism Score next to this item does not affect my main result: populism has an independent impact on environmental performance, which is not driven by a state's form of government.

I also examined a moderating effect of ideology. Although populism is largely seen as orthogonal to left-right ideological positions (Rooduijn and Akkerman 2017; Otjes and Louwerse 2015; Akkerman et al. 2017; Huber and Ruth 2017; Huber and Schimpf 2017; Taggart 2002; Forchtner and Kølvraa 2015) and, indeed, the main characteristics of populism are the same across ideologies (Mudde 2004), scholars increasingly analyze the relationship between the two concepts (Otjes and Louwerse 2015; Akkerman et al. 2017; Huber and Ruth 2017; Huber and Schimpf 2017). The theoretical rationale behind a moderating influence may be that right-wing populists define and see "the good people" and "corrupt elites" somewhat differently than left-wing populists. That is, the former have a "strong cultural and nativist aspect" in its discourse, while the latter's discourse is mainly defined in economic terms (Forchtner and Kølvraa 2015: 199; Huber and Schimpf 2017). The GPD (Hawkins et al. 2019) comprises a variable capturing the general ideology of a leader and distinguishes between left-wing, liberal/center ideologies, and right-wing positions. Using this information, I created three dichotomous variables for each category. Model 4 summarizes the modified specification of this and I leave right-wing ideologies out as the baseline for comparison. In Model 5, I also interact the binary ideology variables with Populism Score. Nonetheless, Table 2 presents only weak evidence for an influence of political ideology on environmental performance and I do not identify a strong moderating influence of this factor, since the interaction terms are statistically insignificant.

Table 3.

The Influence of Civil Society Strength

\begin{tabular}{ll}
\hline & Model 6 \\
\hline Populism Score & 0.101 \\
& $(0.047)^{* *}$ \\
Civil Society Strength & -0.482 \\
& $(0.258)^{*}$ \\
Population $($ ln) & 0.098 \\
& $(0.028)^{* * *}$ \\
GDP per capita $(\ln )$ & 0.480
\end{tabular}




\begin{tabular}{ll} 
& $(0.059)^{* * *}$ \\
State Capacity & -0.183 \\
& $(0.065)^{* * *}$ \\
Unemployment $(\ln )$ & 0.147 \\
& $(0.041)^{* * *}$ \\
Manufacturing & -0.003 \\
& $(0.008)$ \\
Globalization & 0.036 \\
& $(0.008)^{* * *}$ \\
Democracy & -0.010 \\
& $(0.011)$ \\
Constant & -6.019 \\
& $(0.689)^{* * *}$ \\
\hline$N$ & 193 \\
Random Intercept & Yes \\
Time Fixed Effects & Yes \\
\hline
\end{tabular}

Note: Standard errors clustered on leaders in parentheses; $*$ significant at $10 \%$; ** significant at $5 \%$; *** significant at $1 \%$ (two-tailed).

The research's focus is on state leaders and their populist attitudes. This does not imply, however, that pressure groups at the grass-roots, e.g., Extinction Rebellion, cannot be "populists" or that they are without influence. While there is no systematic data on nongovernmental groups, social movements, and populism, I re-estimated my main model while including a variable on the strength of civil society. Clearly, this analysis does not capture populist grass-roots movements, but I can proxy some of the influence stemming from civil society on environmental politics. To this end, I rely on the Core Civil Society Index by the V-Dem data set: ${ }^{6}$ this variable provides "a measure of a robust civil society, understood as one that enjoys autonomy from the state and in which citizens freely and actively pursue their political and civic goals, however conceived." Higher values pertain to more autonomy and greater influence. When including this variable in the main model (see Table 3), the core result is basically unchanged: populism is associated with more emissions. At the same time, however, there is also some evidence that civil society can exert an influence in that I obtain a negative and significant estimate: the stronger the civil society in a country, the lower the emissions per capita. This mirrors existing findings on environmental non-governmental organizations in international regimes (e.g., Böhmelt and Betzold 2013). However, this is only a preliminary analysis and future work may examine more thoroughly the links between non-governmental groups, social movements, populism, and environmental quality.

\footnotetext{
${ }^{6}$ See online at: https://www.v-dem.net.
} 


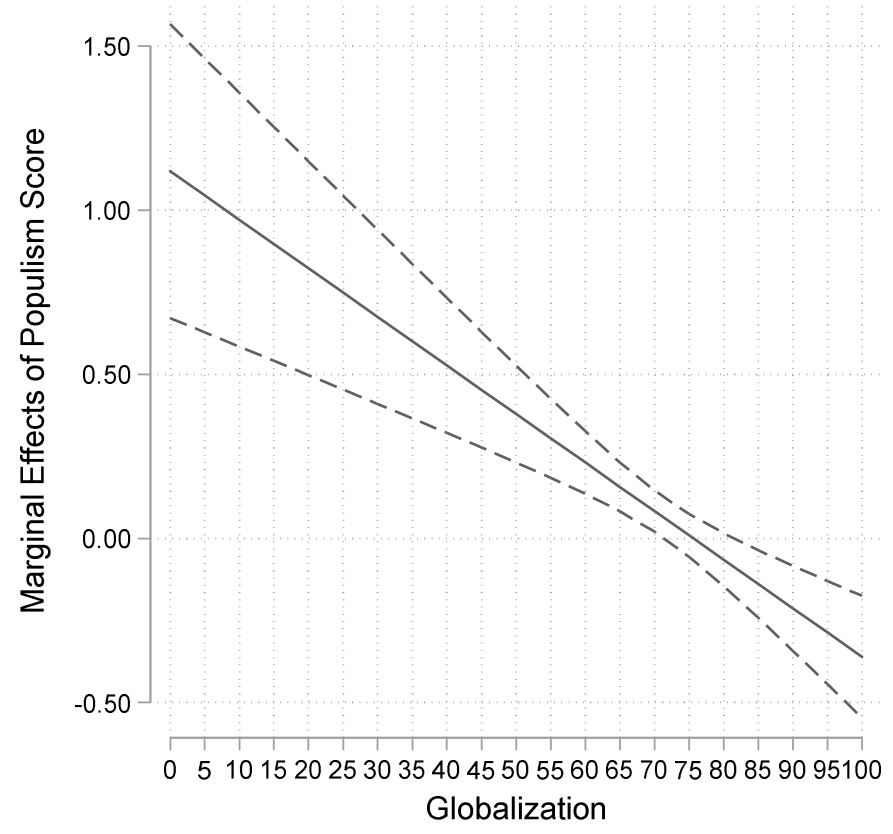

Figure 3.

Effect of Populism on Environmental Outcomes Moderated by Globalization

Note: Graph prepared by author; dashed lines indicate the $90 \%$ confidence interval.

Finally, a state's embeddedness in the international system influences its environmental performance. Ward (2006) examines the network of international regimes and finds that even non-environmental institutions could improve countries' environmental quality "at home." Spilker (2012) concentrates on the general network of environmental and non-environmental international organizations (IOs): according to her results, such IOs can be helpful, including by constraining leaders' power to pursue less environmentally-friendly policies. Finally, Cao and Prakash (2012) study environmental performance with a view towards states' embeddedness in the global trade network. Those and related works suggest that populist leaders might also be constrained by the international level or that they, once in power, ignore or fail to implement international commitments. To this end, I employ the KOF Globalization Index, which also comprises the number of IOs in which a country is member and the number of international treaties signed between two or more states and I interact it with Populism Score. Table 4 and Figure 3 stress that there is some evidence for a constraining effect stemming from the international level.

Table 4.

Robustness Checks: Moderation via Globalization

\begin{tabular}{ll}
\hline & Model 7 \\
\hline Populism Score & 1.119 \\
& $(0.272)^{* * *}$ \\
Populism Score * Globalization & -0.015 \\
& $(0.004)^{* * *}$ \\
Population $($ ln $)$ & 0.105 \\
& $(0.028)^{* * *}$ \\
GDP per capita $($ ln $)$ & 0.449 \\
State Capacity & $(0.047)^{* * *}$ \\
& -0.257
\end{tabular}




\begin{tabular}{ll} 
& $(0.061)^{* * *}$ \\
Unemployment $(\ln )$ & 0.134 \\
& $(0.039)^{* * *}$ \\
Manufacturing & -0.007 \\
& $(0.008)$ \\
Globalization & 0.048 \\
& $(0.007)^{* * *}$ \\
Democracy & -0.020 \\
& $(0.011)^{*}$ \\
Constant & -6.923 \\
& $(0.713)^{* * *}$ \\
\hline$N$ & 193 \\
Random Intercept & Yes \\
Time Fixed Effects & Yes \\
\hline
\end{tabular}

Note: Standard errors clustered on leaders in parentheses; * significant at $10 \%$; ** significant at $5 \%$; *** significant at $1 \%$ (two-tailed).

That is, the theoretical range of Globalization is $[0 ; 100]$ with higher values standing for more embeddedness in the international system. According to the interaction, the positive impact of Populism Score is significantly given and remains robust, but only for low to high values of Globalization. After a threshold has been passed, which is at around a value of 85 of Globalization, Populism Score is even negatively signed and statistically significant. Hence, similar to the domestic level, populists may have the incentive to overcome checks and balances as well as commitments internationally. Yet, the more embedded a country is internationally, the more difficult this becomes. In fact, Figure 3 suggests that populists are not successful at all in this, as the graph points to a highly constraining impact of the international system and states' commitments therein

\section{Conclusion}

How is populism related to environmental politics? Previous research focuses more and more on the consequences of populism, "a thin-centered ideology that considers society to be ultimately separated into two homogeneous and antagonistic groups, [...] and which argues that politics should be an expression of the volonté générale (general will) of the people" (Mudde 2004, 543), also in the context of environmental politics. Existing work has mainly been of a theoretical nature or sought to assess the influence of populist attitudes on environmental views at the individual level. This article seeks to build on and extend these studies by providing the first systematic analysis of the impact of populist leadership on countries' environmental performance at the outcome level.

The theoretical argument is based on two mechanisms: one that focuses on populists' rejection of elitist politics, which includes environmental politics; a second one concentrates on populists undermining political institutions that are usually favorable to better environmental performance. The empirical analysis based on quantitative data that combine leaders' populist tendencies and environmental quality at the outcome level, as captured by $\mathrm{CO}_{2}$ emissions, provides strong and robust evidence for my claims: populism lowers environmental performance. A series of robustness checks in the appendix adds to the confidence in this result: I considered term fixed effects and a lagged dependent variable; I replaced the standard errors by panel-corrected ones and I re-estimated the main model using 
random effects in a regular OLS setup and the Arrelano-Bond estimator; ${ }^{7}$ I model a curvilinear effect stemming from income and I replaced the dependent variable by alternatives, i.e., a variable capturing environmental policy outputs, a measure on efficiency, and a variable on ecological footprint; I include a variable on veto players next to an estimation with jackknifed standard errors; I also model potentially moderating influences from regime type and single-party governments; and I take account of fossil fuel production. All additional models are summarized in the appendix and further support my main result.

There are several policy implications and avenues for future research that emerge from this study. First, this research adds to those studies arguing for the ineffectiveness of populist leadership and, in turn, individuals' electoral choices. Populists are, despite their claims, rather ineffective in providing public goods, including environmental quality. Large segments of the society are also systematically excluded from decision-making, which further hampers a deliberative environmental policy process. Hence, despite their promises, voters would be ill-advised to cast their vote for populists if they care about environmental performance. Even if they are skeptical about "current elites" in power, populists are unlikely to make things better and, in fact, the cure may well be worse than the disease here.

Second, despite my focus on state leaders, it should not be ignored that other political parties, junior coalition partners, or non-governmental actors also have the potential to influence environmental politics in important ways (see, e.g., Betsill and Corell 2001). Data limitations prevent me from exploring this issue in detail here (although I present some preliminary findings on civil society above and single-party governments in the appendix), but future work may want to analyze the impact of populist grass-roots movements, junior coalition partners, and opposition parties on the environment thoroughly. In this context, a general discussion of the quality of the populism data I use may seem warranted (see also Wuttke et al. 2020). On one hand, the GPD (Hawkins et al. 2019) is the only time-series cross-sectional data set covering a large number of countries and years while seeking to code all elements of populism as thoroughly as possible. On the other hand, the focus on leaders is based on a series of assumptions and future data compilations may seek to address populism of other actors and entities, e.g., party platforms. Consider here, for instance, the Populism and Political Parties Expert Survey by Meijers and Zaslove (2020), which covers up to 250 political parties in 28 European countries. The shortcoming of these data is, however, that they only capture parties that were represented in parliament in $2017 / 2018$. That is, these data are not time varying.

Third, the argument I have developed is based on two interrelated, yet different mechanisms. Experimental or more qualitative work could try to disentangle the two processes, arguably shedding light on which one is more influential. Fourth, the available data coverage dictates my spatio-temporal scope: while my analyses are based on 66 countries between 1994 and 2016 and, thus, I can generalize the findings obtained, additional data-compilation efforts are in need to get more information about populism and populist leadership in further countries and years as well. Fifth, I concentrate on the impact of populism on environmental performance, and this relationship between politics and the environment is likely to become more salient as the latter deteriorates. This implies, in turn, that the direction of influence may vary. In fact, recent research strongly points to a simultaneous relationship between these

\footnotetext{
7 Emissions, population, and GDP per capita may be characterized by an upward trend in most countries. However, the inclusion or exclusion of population or income do not affect the results, while I have replaced the outcome variable by alternatives that are arguably less affected by trending in the appendix. Finally, the Arrelano-Bond estimator (also in the appendix) further addresses issues surrounding autocorrelation, endogeneity, and trending.
} 
factors (e.g., Bakaki et al. 2020) and examining this in greater detail than I can do here seems like an important avenue for future work. Finally, while I sought to examine some conditional influences and scope conditions of my argument via the analysis summarized in Table 2, other, perhaps more influential intervening effects exist. Future studies may want to uncover these and further shed light on the impact of populism on environmental politics.

Tobias Böhmelt is Professor of Government at the University of Essex. His research focuses on international relations and comparative politics. His work has been published in journals such as the American Political Science Review, the American Journal of Political Science, the Journal of Politics, International Studies Quarterly, World Politics, International Organization, Comparative Political Studies, Nature Sustainability, and Nature Climate Change, among others. He is also one of the editors of the British Journal of Political Science.

\section{References}

Akkerman, Tjitske. 2012. Comparing Radical Right Parties in Government: Immigration and Integration Policies in Nine Countries (1996-2010). West European Politics 35 (3): 511529.

Akkerman, Agnes, Cas Mudde, and Andrej Zaslove. 2014. How Populist Are the People? Measuring Populist Attitudes in Voters. Comparative Political Studies 47 (9): 1324-1353.

Akkerman, Agnes, Andrej Zaslove, and Bram Spruyt. 2017. 'We the People' Or 'We the Peoples'? A Comparison of Support for the Populist Radical Right and Populist Radical Left in the Netherlands. Swiss Political Science Review 23 (4): 377-403.

Anderson, Brilé, Tobias Böhmelt, and Hugh Ward. 2017. Public Opinion and Environmental Policy Output: A Cross-National Analysis of Energy Policies in Europe. Environmental Research Letters 12 (11): 114011.

Arrow, Kenneth J. 1963. Social Choice and Individual Values. New York: John Wiley and Sons.

Bakaki, Zorzeta, Tobias Böhmelt, and Hugh Ward. 2020. The Triangular Relationship between Public Concern for Environmental Issues, Policy Output, and Media Attention. Environmental Politics: Forthcoming.

Beeson, Mark. 2019. Environmental Populism: The Politics of Survival in the Anthropocene. New York: Springer.

Bernauer, Thomas, and Tobias Böhmelt. 2013. Are Economically "Kinder, Gentler Societies" Also Greener? Environmental Science \& Technology 47 (21): 11993-12001.

Bernauer, Thomas, and Vally Koubi. 2009. Political Determinants of Environmental Quality. Ecological Economics 68 (5): 1355-1365.

Bernauer, Thomas, Tobias Böhmelt, and Vally Koubi. 2013. Is There a Democracy-Civil Society Paradox in Global Environmental Governance? Global Environmental Politics 13 (1): 88-107.

Betsill, Michele M., and Elisabeth Corell. 2001. NGO Influence in International Environmental Negotiations: A Framework for Analysis. Global Environmental Politics 1 (4): $65-85$.

Böhmelt, Tobias, and Carola Betzold. 2013. The Impact Of Environmental Interest Groups in International Negotiations: Do ENGOs Induce Stronger Environmental Commitments? International Environmental Agreements 13 (2): 127-151.

Böhmelt, Tobias, Marit Böker, and Hugh Ward. 2016. Democratic Inclusiveness, Climate Policy Outputs, and Climate Policy Outcomes. Democratization 23 (7): 1272-1291. 
Böhmelt, Tobias, Farzad Vaziri, and Hugh Ward. 2018. Does Green Taxation Drive Countries Towards the Carbon Efficiency Frontier? Journal of Public Policy 38 (4): 481-509.

Bonikowski, Bart. 2019. Trump's Populism: The Mobilization of Nationalist Cleavages and the Future of US Democracy. In Kurt Weyland and Raúl L. Madrid (eds.). When Democracy Trumps Populism: European and Latin America Lessons for the United States. Cambridge: Cambridge University Press, pp. 110-131.

Bos, Linda, Wouter van der Brug, and Claes de Vreese. 2013. An Experimental Test of the Impact of Style and Rhetoric on the Perception of Rightwing Populist and Mainstream Party Leaders. Acta Politica 48 (2): 192-208

Bueno de Mesquita, Bruce, Alastair Smith, Randolph M. Siverson, and James D. Morrow. 2003. The Logic of Political Survival. Cambridge, MA: MIT Press.

Busby, Ethan, Joshua R. Gubler, and Kirk A. Hawkins. 2019. Framing and Blame Attribution in Populist Rhetoric. Journal of Politics 81 (2): 616-630.

Canovan, Margaret. 1981. Populism. London: Junction Books.

Cao, Xun, and Aseem Prakash. 2012. Trade Competition and Environmental Regulations: Domestic Political Constraints and Issue Visibility. Journal of Politics 74 (1): 66-82.

Caramani, Daniele. 2017. Will vs. Reason: The Populist and Technocratic Forms of Political Representation and Their Critique to Party Government. American Political Science Review 111 (1): 54-67.

Castanho Silva, Bruno, et al. 2018. Public Opinion Surveys: A New Scale. In Kirk A. Hawkins, Ryan E. Carlin, Levente Littvay, Cristóbal Rovira Kaltwasser (eds.). The Ideational Approach to Populism: Concept, Theory, and Method. London: Routledge, pp. 150-179.

Castanho Silva, Bruno, et al. 2020. An Empirical Comparison of Seven Populist Attitudes Scales. Political Research Quarterly 73 (2): 409-424.

Chang, Chun-Ping, Chien-Chiang Lee, and Aziz N. Berdiev. 2015. The Impact of Government Ideology on Energy Efficiency: Evidence From Panel Data. Energy Efficiency 8 (6): 1181-1199.

Congleton, Roger D. 1992. Political Institutions and Pollution Control. Review of Economics and Statistics 74 (3): 412-421.

Dahl, Robert A. 1956. A Preface to Democratic Theory. Chicago, IL: Chicago University Press.

Dahl, Robert A. 1971. Polyarchy: Participation and Opposition. New Haven, CT: Yale University Press.

Dasgupta, Shouro, and Enrica De Cian. 2018. The Influence of Institutions, Governance, and Public Opinion on the Environment: Synthesized Findings From Applied Econometrics Studies. Energy Research \& Social Science 43 (1): 77-95.

Downs, Anthony. 1957. An Economic Theory of Democracy. New York: Harper.

Doyle, David. 2011. The Legitimacy of Political Institutions: Explaining Contemporary Populism in Latin America. Comparative Political Studies 44 (11): 1447-1473.

Dreher, Axel. 2006. Does Globalization Affect Growth? Evidence from a new Index of Globalization. Applied Economics 38 (10): 1091-1110.

Forchtner, Bernhard, and Christoffer Kølvraa. 2015. The Nature of Nationalism: Populist Radical Right Parties on Countryside and Climate. Nature and Culture 10 (2): 199-224.

Freudenberg, Nicholas, and Carol Steinsapir. 1991. Not in our Backyards: The Grassroots Environmental Movement. Society \& Natural Resources 4 (3): 235-245.

Garmann, Sebastian. 2014. Do Government Ideology and Fragmentation Matter for Reducing $\mathrm{CO}_{2}$-Emissions? Empirical Evidence from OECD Countries. Ecological Economics 105 (1): $1-10$.

Gassebner, Martin, Michael J. Lamla, and Jan-Egbert Sturm. 2011. Determinants of Pollution: What Do We Really Know? Oxford Economic Papers 63 (3): 568-595. 
Hameleers, Michael, and Desirée Schmuck. 2017. It's Us Against Them: A Comparative Experiment on the Effects of Populist Messages Communicated via Social Media. Information, Communication \& Society 20 (9): 1425-1444.

Hawkins, Kirk A. 2003. Populism in Venezuela: The Rise of Chavismo. Third World Quarterly 24 (6): 1137-1160.

Hawkins, Kirk A., et al. 2019. Measuring Populist Discourse: The Global Populism Database. Paper presented at the 2019 EPSA Annual Conference in Belfast, UK, June 2022.

Hawkins, Kirk A., and Cristóbal Rovira Kaltwasser. 2018. Introduction: The Ideational Approach. In Kirk A. Hawkins, Ryan E. Carlin, Levente Littvay, Cristóbal Rovira Kaltwasser (eds.). The Ideational Approach to Populism: Concept, Theory, and Method. London: Routledge, pp. 1-24.

Hay, Colin, and Garry Stoker. 2009. Revitalizing Politics: Have We Lost the Plot? Representation 45 (3): 225-236.

Hobolt, Sara B. 2016. The Brexit Vote: A Divided Nation, a Divided Continent. Journal of European Public Policy 23 (9): 1259-1277.

Hornsey, Matthew J., Emily Harris, and Kelly S. Fielding. 2018. Relationships among Conspiratorial Beliefs, Conservatism, and Climate Skepticism across Nations. Nature Climate Change 8 (1): 614-620.

Huber, Robert. 2020. The Role of Populist Attitudes in Explaining Climate Change Skepticism and Support for Environmental Protection. Environmental Politics: Forthcoming.

Huber, Robert, Lukas Fesenfeld, and Thomas Bernauer. 2020. Political Populism, Responsiveness, and Public Support for Climate Mitigation. Climate Policy: Forthcoming.

Huber, Robert, and Saskia Ruth. 2017. Mind the Gap! Populism, Participation, and Representation in Europe. Swiss Political Science Review 23 (4): 462-484.

Huber, Robert, and Christian Schimpf. 2016. Friend or Foe? Testing the Influence of Populism on Democratic Quality in Latin America. Political Studies 64 (4): 872-889.

Huber, Robert, and Christian Schimpf. 2017. On the Distinct Effects of Left-Wing and RightWing Populism on Democratic Quality. Politics and Governance 5 (4): 146-165.

Inglehart, Robert. 1995. Public Support for Environmental Protection: Objective Problems and Subjective Values in 43 Societies. PS: Political Science and Politics 28 (1): 57-72.

Jahn, Detlef. 1998. Environmental Performance and Policy Regimes: Explaining Variations in 18 OECD-Countries. Policy Sciences 31 (2): 107-131.

Jahn, Detlef. 2016. The Politics of Environmental Performance. Cambridge: Cambridge University Press.

Knill, Christoph, Marc Debus, and Stephan Heichel. 2010. Do Parties Matter in Internationalized Policy Areas? The Impact of Political Parties on Environmental Policy Outputs in 18 OECD Countries, 1970-2000. European Journal of Political Research 49 (3): 301-336.

Lake, David, and Matthew Baum. 2001. The Invisible Hand of Democracy: Political Control and the Provision of Public Service. Comparative Political Studies 34 (6): 587-621.

Leinaweaver, Justin, and Robert Thomson. 2016. Greener Governments: Partisan Ideologies, Executive Institutions, and Environmental Policies. Environmental Politics 25 (4): 633660.

Li, Quan, and Rafael Reuveny. 2006. Democracy and Environmental Degradation. International Studies Quarterly 50 (4): 935-956.

Lockwood, Matthew. 2018. Right-Wing Populism and the Climate Change Agenda: Exploring the Linkages. Environmental Politics 27 (4): 712-732.

Meijers, Maurits J., and Andrej Zaslove. 2020. Measuring Populism in Political Parties: Appraisal of a New Approach. Comparative Political Studies: Forthcoming. 
McGuire, Martin, and Mancur Olson. 1996. The Economics of Autocracy and Majority Rule: The Invisible Hand and the Use of Force. Journal of Economic Literature 34 (2): 72-96.

Morrison, Denton, and Riley Dunlap. 1986. Environmentalism and Elitism: A Conceptual and Empirical Analysis. Environmental Management 10 (5): 581-589.

Mudde, Cas. 2004. The Populist Zeitgeist. Government and Opposition 39 (4): 541-563.

Mudde, Cas, and Cristóbal Rovira Kaltwasser. 2012. Populism and (Liberal) Democracy: A Framework for Analysis. in Cas Mudde and Cristóbal Rovira Kaltwasser (eds.) Populism in Europe and the Americas. Cambridge: Cambridge University Press, pp. 1-26.

Neumayer, Eric. 2003. Are Left-Wing Party Strength and Corporatism Good for the Environment? Evidence from Panel Analysis of Air Pollution in OECD Countries. Ecological Economics 45 (1): 203-220.

Neumayer, Eric. 2004. The Environment, Left-Wing Political Orientation and Ecological Economics. Ecological Economics 51 (1): 167-175.

Niskanen, William. 1997. Autocratic, Democratic, and Optimal Government. Economic Inquire 35 (3): 464-479.

Oliver, J. Eric, and Wendy M. Rahn. 2016. Rise of the Trumpenvolk: Populism in the 2016 Election. Annals of the American Academy of Political and Social Science 667 (1): 189206.

Otjes, Simon, and Tom Louwerse. 2015. Populists in Parliament: Comparing Left-Wing and Right-Wing Populism in the Netherlands. Political Studies 63 (1): 60-79.

Page, Benjamin I., and Robert Y. Shapiro. 1983. Effects of Public Opinion on Policy. American Political Science Review 77 (1): 175-190.

Panizza, Francisco. 2000. Neopopulism and Its Limits in Collor's Brazil. Bulletin of Latin American Research 19 (2): 177-192.

Payne, Roger A. 1995. Freedom and the Environment. Journal of Democracy 6 (3): 41-55.

Poloni-Staudinger, Lori M. 2008. Are Consensus Democracies More Environmentally Effective? Environmental Politics 17 (3): 410-430.

Roberts, Kenneth. 2007. Latin America's Populist Revival. SAIS Review 27 (1): 3-15.

Rooduijn, Matthijs. 2019. State of the Field: How to Study Populism and Adjacent Topics? A Plea for Both More and Less Focus. European Journal of Political Research 58 (1): 362372.

Rooduijn, Matthijs, and Tjitske Akkerman. 2017. Flank Attacks: Populism and Left-Right Radicalism in Western Europe. Party Politics 23 (3): 193-204.

Rooduijn, Matthijs, Wouter Van Der Brug, and Sarah L. De Lange. 2016. Expressing or Fueling Discontent? The Relationship Between Populist Voting and Political Discontent. Electoral Studies 43 (1): 32-40.

Schulze, Kai. 2014. Do Parties Matter for International Environmental Cooperation? An Analysis of Environmental Treaty Participation by Advanced Industrialized Democracies. Environmental Politics 23 (1): 115-139.

Spence, Alexa, Wouter Poortinga, and Nick Pidgeon. 2012. The Psychological Distance of Climate Change: Psychological Distance of Climate Change. Risk Analysis 32 (6): 957972.

Spilker, Gabriele. 2012. Helpful Organizations: Membership in Inter-Governmental Organizations and Environmental Quality in Developing Countries. British Journal of Political Science 42 (2): 345-370.

Stadelmann-Steffen, Isabelle. 2011. Citizens as Veto Players: Climate Change Policy and the Constraints of Direct Democracy. Environmental Politics 20 (4): 485-507.

Taggart, Paul. 2002. Populism and the Pathology of Representative Politics. In: Yves Mény and Yves Surel (eds.). Democracies and the Populist Challenge. London: Palgrave, pp. 6280 . 
Tobin, Paul. 2017. Leaders and Laggards: Climate Policy Ambition in Developed States. Global Environmental Politics 17 (4): 28-47.

Torre, Carlos de la. 2015. The Promise and Perils of Populism: Global Perspectives. Lexington: KY: University Press of Kentucky.

Tsebelis, George. 1995. Decision Making in Political Systems: Veto Players in Presidentialism, Parliamentarism, Multicameralism and Multipartyism. British Journal of Political Science 25 (3): 289-325.

Tsebelis, George. 1999. Veto Players and Law Production in Parliamentary Democracies: An Empirical Analysis. American Political Science Review 93 (3): 591-608.

Van Hauwaert, Steven, Christian Schimpf, and Flavio Azevedo. 2020. The Measurement of Populist Attitudes: Testing Cross-National Scales Using Itemresponse Theory. Politics 40 (1): 3-21.

Ward, Hugh. 2006. International Linkages and Environmental Sustainability: The Effectiveness of the Regime Network. Journal of Peace Research 43 (2): 149-166.

Ward, Hugh. 2008. Liberal Democracy and Sustainability. Environmental Politics 17 (3): 386-409.

Ward, Hugh, and Xun Cao. 2012. Domestic and International Influences on Green Taxation. Comparative Political Studies 45 (9): 1075-1103.

Weber, Elke U. 2016. What Shapes Perceptions of Climate Change? New Research Since 2010. Wiley Interdisciplinary Reviews: Climate Change 7 (1): 125-134.

Wetts, Rachel. 2020. Models and Morals: Elite-Oriented and Value-Neutral Discourse Dominates American Organizations' Framings of Climate Change. Social Forces 98 (3): 1339-1369

Wuttke, Alexander, Christian Schimpf, and Harald Schoen. 2020. When the Whole is Greater than the Sum of its Parts: On the Conceptualization and Measurement of Populist Attitudes and other Multidimensional Constructs. American Political Science Review 114 (2): 356374. 


\section{Populism and Environmental Performance - Appendix}

This appendix summarizes a series of additional models that further support the main article's findings. These include:

- I considered term fixed effects and a lagged dependent variable.

- I replaced the standard errors by panel-corrected ones.

- I re-estimated the main model using random effects in a regular OLS setup and use the Arrelano-Bond estimator.

- I model a curvilinear effect stemming from income.

- I replaced the dependent variable by alternatives, i.e., a variable capturing environmental policy outputs and a measure on efficiency.

- I include a variable on veto players.

- I jackknifed the standard errors.

- Using a binary variable on single-party governments, I study a moderating impact on the effect of populism.

- I also explore whether there is a moderating influence stemming from regime type.

- Controlling for fossil fuel production. 


\section{Different Model Specifications}

The main text's analysis is based on multi-level models with year fixed effects and random intercepts for leaders. This approach not only acknowledges for the hierarchical nature of the data and corresponding dependencies across levels, but also addresses influences stemming from unobserved factors. While this comprehensively deals with confounding factors, I also considered other specifications. First, I additionally include fixed effects for leaders' terms to control for unobserved, time-invariant term determinants (Model 1). Second, I also include a one-year lagged dependent variable to capture path dependencies in the outcome variable (Model 2). Third, I estimate Prais-Winsten regression with heteroskedastic panels corrected standard errors and a one-year autocorrelation process instead of the multi-level model (Model 3). Panel-level heteroskedastic errors address country-specific idiosyncrasies. Fourth, I use random effects in a regular OLS setup (Model 4). And, fifth, I employ the ArellanoBond estimator, which contains both the levels and the first difference equations to account for trending in the data. Models 1-5 in this appendix, which are all based on Model 3 of the main text, summarize these additional models and show that the main effect remains robust: populism is positively related to $\mathrm{CO}_{2}$ emissions and, hence, detrimental for the environment.

Table A1.

Robustness Checks: Varying Model Specifications

\begin{tabular}{|c|c|c|c|c|c|}
\hline & Model 1 & Model 2 & Model 3 & Model 4 & Model 5 \\
\hline Lagged Dependent Variable & & $\begin{array}{l}0.987 \\
(0.011)^{* * * *}\end{array}$ & & & \\
\hline Populism Score & $\begin{array}{l}0.115 \\
(0.042)^{* * *}\end{array}$ & $\begin{array}{l}0.027 \\
(0.015)^{*}\end{array}$ & $\begin{array}{l}0.217 \\
(0.091)^{* *}\end{array}$ & $\begin{array}{l}0.137 \\
(0.057)^{* *}\end{array}$ & $\begin{array}{l}0.165 \\
(0.099)^{*}\end{array}$ \\
\hline Population (ln) & $\begin{array}{l}0.070 \\
(0.032)^{* *}\end{array}$ & $\begin{array}{l}-0.000 \\
(0.005)\end{array}$ & $\begin{array}{l}0.061 \\
(0.025)^{* *}\end{array}$ & $\begin{array}{l}0.070 \\
(0.032)^{* *}\end{array}$ & $\begin{array}{c}0.048 \\
(0.035)\end{array}$ \\
\hline GDP per capita (ln) & $\begin{array}{l}0.553 \\
(0.033) * * *\end{array}$ & $\begin{array}{c}0.002 \\
(0.010)\end{array}$ & $\begin{array}{l}0.669 \\
(0.036) * * *\end{array}$ & $\begin{array}{l}0.569 \\
(0.038) * * *\end{array}$ & $\begin{array}{l}0.693 \\
(0.039)^{* * *}\end{array}$ \\
\hline Democracy & $\begin{array}{c}0.001 \\
(0.010)\end{array}$ & $\begin{array}{l}-0.000 \\
(0.001)\end{array}$ & $\begin{array}{l}-0.043 \\
(0.011) * * *\end{array}$ & $\begin{array}{l}-0.005 \\
(0.009)\end{array}$ & $\begin{array}{l}-0.053 \\
(0.016) * * *\end{array}$ \\
\hline Constant & $\begin{array}{l}-4.061 \\
(0.535) * * *\end{array}$ & $\begin{array}{l}-0.030 \\
(0.085)\end{array}$ & $\begin{array}{l}-4.576 \\
(0.471) * * *\end{array}$ & $\begin{array}{l}-4.164 \\
(0.685) * * *\end{array}$ & $\begin{array}{l}-5.491 \\
(0.605)^{* * *}\end{array}$ \\
\hline$N$ & 205 & 205 & 205 & 205 & 205 \\
\hline
\end{tabular}




\begin{tabular}{lccccc} 
Random Intercept & Yes & Yes & No & Yes & No \\
Term Fixed Effects & Yes & No & No & No & No \\
Time Fixed Effects & Yes & Yes & Yes & Yes & Yes \\
\hline
\end{tabular}

Note: Standard errors in parentheses; * significant at $10 \%$; ** significant at 5\%; *** significant at $1 \%$ (twotailed).

\section{Curvilinear Effect from Income}

In the main text's models, I merely included an income variable without any further alterations. Much of the literature, however, models a curvilinear effect in order to capture what is commonly known as the Environmental Kuznets Curve: environmental quality first decreases until a tipping point is reached, after which environmental performance improves with higher development - and income. In order to mode this in my setup, I have added a squared income term to the main text's Model 3 and re-run the estimation. While the main result remains robust, I find no evidence for a curvilinear effect.

Table A2.

Robustness Checks: Curvilinear Effect from Income

\begin{tabular}{lc}
\hline & Model 6 \\
\hline Populism Score & 0.124 \\
& $(0.040)^{* * *}$ \\
Population (ln) & 0.070 \\
& $(0.032)^{* *}$ \\
GDP per capita $($ ln $)$ & 0.463 \\
& $(0.231)^{* *}$ \\
GDP per capita $(\text { ln })^{2}$ & 0.005 \\
& $(0.013)$ \\
Democracy & -0.002 \\
& $(0.010)$ \\
Constant & -3.648 \\
& $(1.178)^{* * *}$ \\
\hline$N$ & 205 \\
Random Intercept & Yes \\
Time Fixed Effects & Yes \\
\hline
\end{tabular}

Note: Standard errors clustered on leaders in parentheses; $*$ significant at $10 \%$; ** significant at $5 \%$; *** significant at $1 \%$ (two-tailed).

\section{Alternative Dependent Variables}

Böhmelt et al. (2018) emphasize that several variables have been used in the literature to capture environmental quality. These items, although addressing the same, underlying concept, do serve different purposes and no single measure is ideal for all circumstances. To this end, I assess the robustness of my main finding using two different dependent variables that differ from the measure used in the main text. First, I employ the carbon-efficiency measure from Böhmelt et al. (2018) as another outcome-variable alternative. This variable, called Environmental Input Efficiency captures countries' distance from the carbon emission efficiency frontier, benchmarking them against comparable states. In other words, I address the question of why some countries have higher emissions than others that are at least as 
economically developed and are no more advantaged in terms of technological possibilities. Environmental Input Efficiency thus measures whether states have fully exploited possibilities for progress on climate change in the short to medium term.

I use data from the World Bank Development Indicators again to capture carbon emissions in kilotons per capita and to obtain a measure of per-capita GDP. Under the order-alpha approach, a given country is efficient if no more than 5 percent of other countries in the comparator group have (or had) lower carbon emissions, i.e. the comparator at the $95^{\text {th }}$ percentile for low emissions per capita is the benchmark for calculating efficiency in the year concerned. Environmental Input Efficiency is the ratio of $\mathrm{CO}_{2}$ emissions per capita of the benchmark to those of the country under study. These scores capture a state's distance from the carbon efficiency frontier, e.g., inefficient countries receive scores below 1.

Second, I make use of the policy output data from Anderson et al. (2017). Hence, I now depart from the outcome level and focus on legislative action of state executives. The outputlevel dependent variable captures the number of energy-efficient policies in force up to a given year.

Third, following, e.g., Ward (2006), I examine a measure for sustainability and ecological footprint. The ecological footprint refers to the area (per capita) that is necessary to sustain current patterns of resource use (Lin et al. 2019). The data are available from www.footprintnetwork.org and I focus on the ecological footprint of consumption, i.e., the sum of Footprint of production and imports associated with product or waste minus the footprint of exports associated with product or waste. The variable captures the ecological footprint in standardized global hectares. I log-transform this item and higher values pertain to a larger footprint or a lower environmental performance (see also Wiedmann et al. 2006).

Table A3 summarizes the corresponding findings. In Model 7, I use Environmental Input Efficiency, while Model 8 concentrates on the output-level dependent variable. In Model 9, Ecological Footprint $(\ln )$ is the outcome variable. In Models 7-8, the populism score is now negatively signed - which is expected as higher values stand for more environmental-friendly behavior either in terms of efficiency or outputs here. In Model 9 of Table A3, Populism Score is negatively signed, as larger values of Ecological Footprint (ln) are associated with lower sustainability and environmental performance. The core variable is significant at conventional levels in Table A3, thus emphasizing that my results are robust.

Table A3.

Robustness Checks: Alternative Dependent Variables

\begin{tabular}{llll}
\hline & Model 7 & Model 8 & Model 9 \\
\hline Populism Score & -0.167 & -6.187 & 0.078 \\
& $(0.075)^{* *}$ & $(2.067)^{* * *}$ & $(0.035)^{* *}$ \\
Population (ln) & -0.050 & 4.280 & -0.033 \\
& $(0.018)^{* * *}$ & $(0.768)^{* * *}$ & $(0.016)^{* *}$ \\
GDP per capita $(\ln )$ & -0.098 & 10.176 & 0.392 \\
& $(0.032)^{* * *}$ & $(1.468)^{* * *}$ & $(0.021)^{* * *}$ \\
Democracy & 0.004 & 0.126 & -0.001 \\
& $(0.012)$ & $(0.280)$ & $(0.006)$ \\
Constant & 2.015 & -156.89 & -1.519 \\
& $(0.429)^{* * *}$ & $(17.032)^{* * *}$ & $(0.292)^{* * *}$ \\
\hline$N$ & 205 & 103 & 234
\end{tabular}




\begin{tabular}{lccc} 
Random Intercept & Yes & Yes & Yes \\
Time Fixed Effects & Yes & Yes & Yes \\
\hline
\end{tabular}

Note: Standard errors clustered on leaders in parentheses; $*$ significant at $10 \%$; $* *$ significant at $5 \%$; *** significant at $1 \%$ (two-tailed).

\section{Veto Players}

I discussed veto players and political constraints in the main text, but do not explicitly control for these there. In Model 10 of this appendix, I thus add the political constraints variable from Henisz (2000). As demonstrated there, however, neither does the variable achieve statistical significance nor are my main results affected by the inclusion of this variable in the model.

\section{Table A4.}

Robustness Checks: Veto Players

\begin{tabular}{ll}
\hline & Model 10 \\
\hline Populism Score & 0.122 \\
& $(0.042)^{* * *}$ \\
Veto Players & -0.047 \\
& $(0.182)$ \\
Population (ln) & 0.100 \\
& $(0.029)^{* * *}$ \\
GDP per capita (ln) & 0.468 \\
& $(0.056)^{* * *}$ \\
State Capacity & -0.194 \\
& $(0.068)^{* * *}$ \\
Unemployment $(l n)$ & 0.138 \\
& $(0.041)^{* * *}$ \\
Manufacturing & -0.004 \\
& $(0.008)$ \\
Globalization & 0.037 \\
& $(0.008)^{* * *}$ \\
Democracy & -0.022 \\
& $(0.012)^{*}$ \\
Constant & -6.254 \\
& $(0.723)^{* * *}$ \\
\hline Random Intercept & 192 \\
Time Fixed Effects & Yes \\
\hline
\end{tabular}

Note: Standard errors clustered on leaders in parentheses; * significant at $10 \%$; ** significant at $5 \%$; *** significant at $1 \%$ (two-tailed).

\section{Jackknifing the Standard Errors}

As discussed in the main text, some of the sample countries are characterized by low within variation. To address this issue, I jackknifed the standard errors of the coefficients from my main regression. The main result is robust again to this specification. 
Table A5.

Robustness Checks: Jackknifing the Standard Errors

\begin{tabular}{lc}
\hline & Model 11 \\
\hline Populism Score & 0.165 \\
& $(0.101)^{*}$ \\
Population (ln) & 0.048 \\
& $(0.028)^{*}$ \\
GDP per capita (ln) & 0.693 \\
& $(0.038)^{* * *}$ \\
Democracy & -0.053 \\
& $(0.013)^{* * *}$ \\
Constant & -4.426 \\
& $(0.523)^{* * *}$ \\
\hline$N$ & 205 \\
Random Intercept & Yes \\
Time Fixed Effects & Yes \\
\hline
\end{tabular}

Note: Standard errors in parentheses; * significant at $10 \%$;** significant at $5 \%$; *** significant at $1 \%$ (twotailed).

\section{Single-Party Governments}

The GPD only cover heads of government and, for example, junior coalition partners or opposition parties are not coded. However, we know that these can influence environmental politics as well (see, e.g., Carter 2013; Van Der Heijden 2002) and there are many cases of populist parties included in coalition governments. My analyses thus cannot assess the impact of a populist party that did not control the executive, but still exerted considerable influence over policy via coalition bargaining. Data limitations prevent me from a thorough analysis, but I compiled data on single-party governments and created a binary variable ( 0 for coalition governments in a given year) using Döring and Manow (2012). In turn, I interact this dichotomous variable with Populism Score. Table A6 and Figure A1 summarize the corresponding findings.

The interaction in Model 12 of this appendix is negative and significant. When plotting the marginal effects of Populism Score in light of these results, however, there is little evidence for a major influence. That is, the positive effect of Populism Score on emissions remains robust regardless of whether we look at single-party or coalition governments. The influence is more strongly pronounced for the latter (i.e., when Single-Party Government $=0$ ) as I obtain a point estimate of 0.2 . The marginal effect estimate for single-party governments is smaller (0.086), but the confidence intervals do slightly overlap. Hence, my main result is robust also when controlling for single-party and coalition governments. 
Robustness Checks: Moderation via Single-Party Government

\begin{tabular}{|c|c|}
\hline & Model 12 \\
\hline Populism Score & $\begin{array}{l}0.200 \\
(0.060)^{* * *}\end{array}$ \\
\hline Single-Party Government & $\begin{array}{l}0.085 \\
(0.048)^{*}\end{array}$ \\
\hline Populism Score * Single-Party Government & $\begin{array}{l}-0.114 \\
(0.040) * * *\end{array}$ \\
\hline Population (ln) & $\begin{array}{l}0.100 \\
(0.028) * * *\end{array}$ \\
\hline GDP per capita (ln) & $\begin{array}{l}0.477 \\
(0.062)^{* * *}\end{array}$ \\
\hline State Capacity & $\begin{array}{l}-0.194 \\
(0.076) * *\end{array}$ \\
\hline Unemployment $(\ln )$ & $\begin{array}{l}0.127 \\
(0.042)^{* * *}\end{array}$ \\
\hline Manufacturing & $\begin{array}{l}-0.005 \\
(0.008)\end{array}$ \\
\hline Globalization & $\begin{array}{l}0.037 \\
(0.008)^{* * *}\end{array}$ \\
\hline Democracy & $\begin{array}{l}-0.024 \\
(0.011)^{* *}\end{array}$ \\
\hline Constant & $\begin{array}{l}-6.366 \\
(0.720)^{* * *}\end{array}$ \\
\hline$N$ & 190 \\
\hline Random Intercept & Yes \\
\hline Time Fixed Effects & Yes \\
\hline
\end{tabular}

Note: Standard errors clustered on leaders in parentheses; $*$ significant at $10 \%$; ** significant at $5 \%$; *** significant at $1 \%$ (two-tailed). 


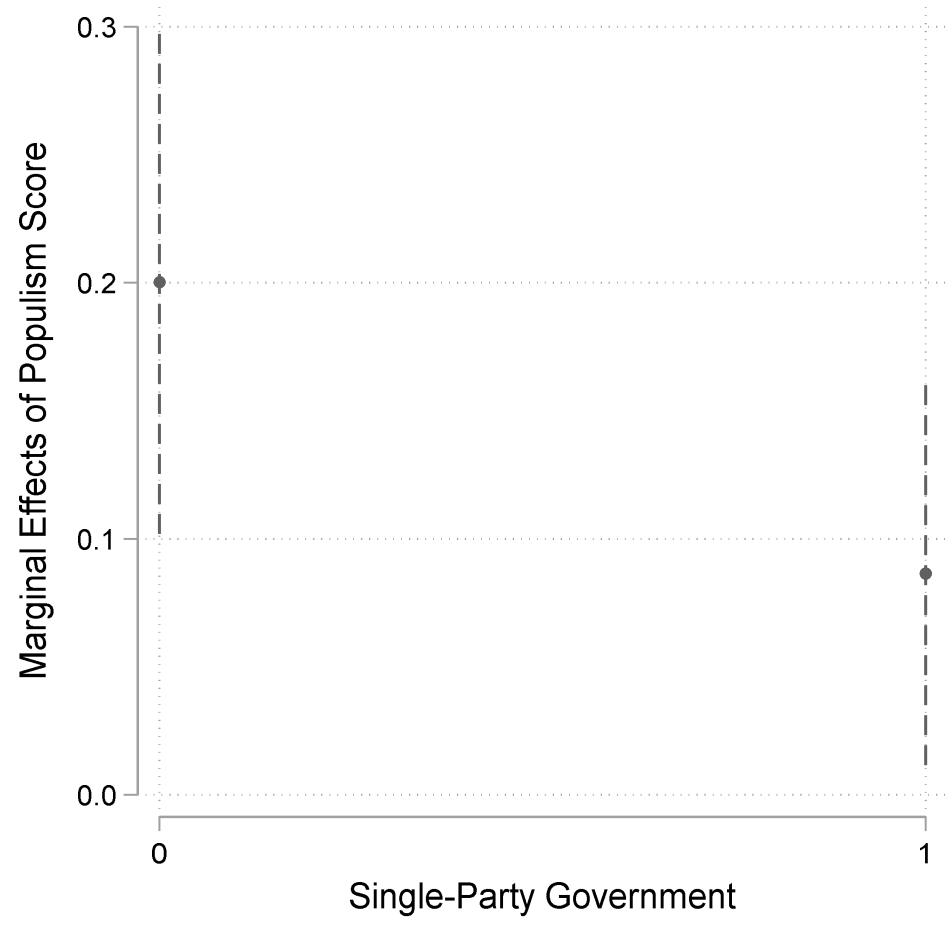

Figure A1.

Effect of Populism on Environmental Outcomes Moderated by Single-Party Government

Note: Graph prepared by author; dashed lines indicate the $90 \%$ confidence interval.

\section{Interaction with Regime Type}

The democracy variable I employ (the polity2 score from the Polity IV data set) is characterized by some temporal and cross-sectional variance over the time period of my analysis. It has been suggested populist leaders may be able to exert a stronger impact when a polity approaches forms of authoritarianism. Such a mechanism would be consistent with my claim about checks and balances, and I examine this in the following via a multiplicative interaction between Populism Score and Democracy. Table A7 and Figure A2 present the results.

A direct interpretation is somewhat more challenging than in the previous model, as Democracy is not binary and the interaction term is statistically insignificant. That said, Populism Score is positively signed and significant at conventional levels, while the estimate of 0.18 captures the marginal effect of Populism Score when holding Democracy at 0 (which is commonly defined as an anocracy). A more substantive interpretation of the interaction is given by Figure A2, which plots the impact of Populism Score on emissions for the different values of Democracy. In essence, there is little evidence for a moderating influence of democratic forms of government and, in fact, a positive effect of populism is given for all values of Democracy (albeit with insignificant point estimates at very low and high levels of that variable). These results imply, although more thorough analyses are necessary in the future, that the second mechanism on checks and balances I develop in the main text may be less crucial than the first one; and they further emphasize that populism could be a missing link explaining some of the contradictory findings in relation to democracy and environmental outcomes.

Table A7. 
Robustness Checks: Moderation via Democracy

\begin{tabular}{ll}
\hline & Model 13 \\
\hline Populism Score & 0.180 \\
& $(0.089)^{* *}$ \\
Populism Score * Democracy & -0.011 \\
& $(0.011)$ \\
Population (ln) & 0.103 \\
& $(0.029)^{* * *}$ \\
GDP per capita (ln) & 0.467 \\
& $(0.059)^{* * *}$ \\
State Capacity & -0.223 \\
& $(0.064)^{* * *}$ \\
Unemployment $(l n)$ & 0.131 \\
& $(0.038)^{* * *}$ \\
Manufacturing & -0.007 \\
& $(0.008)$ \\
Globalization & 0.038 \\
& $(0.007)^{* * *}$ \\
Democracy & -0.005 \\
Constant & $(0.017)$ \\
& -6.412 \\
N & $(0.699)^{* * *}$ \\
Time Fixed Effects & 190 \\
& Yes \\
& \\
&
\end{tabular}

Note: Standard errors clustered on leaders in parentheses; * significant at $10 \%$; ** significant at $5 \%$; *** significant at $1 \%$ (two-tailed).

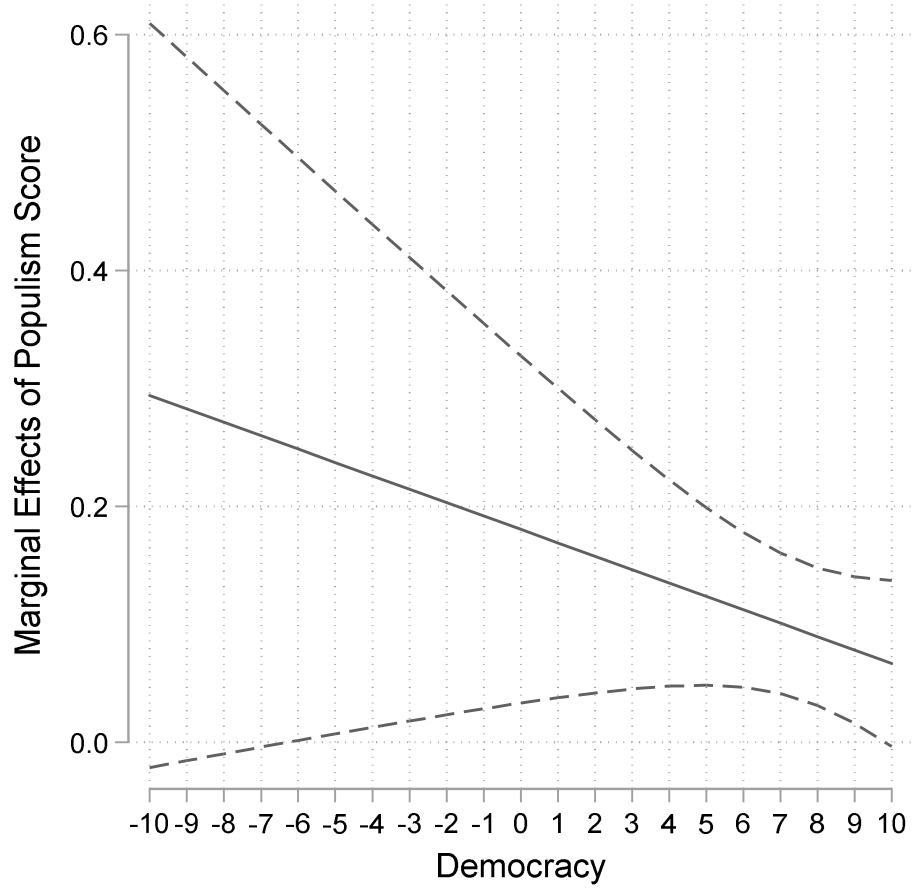




\section{Figure A2.}

Effect of Populism on Environmental Outcomes Moderated by Democracy

Note: Graph prepared by author; dashed lines indicate the $90 \%$ confidence interval

\section{Controlling for Fossil Fuel Production}

The emissions of countries are influenced by a series of factors, which I try to control for as comprehensively and parsimoniously as possible. One determinant not considered so far, however, may we fossil fuel production. I focus on fossil fuel energy consumption as a percentage of total energy consumption. The data are taken from the World Bank Development Indicators, which derives the information from the International Energy Agency. The theoretical rationale behind this indicator is similar to Manufacturing: a higher level of fossil fuel consumption is a proxy for a strong and influential coal and oil industry lobby, and quite a few more populist leaders have played to these in the recent past.

As expected, Fossil Fuel Consumption is positively signed and statistically significant. This mirrors, e.g., Fredriksson and Gaston (2000) who use a similar measure to proxy industry lobby strength. Crucially for my argument, however, Populism Score remains robust as it is positively signed and significant. In other words, populist leadership is detrimental for environmental quality.

\section{Table A8.}

Robustness Checks: Fossil Fuel Consumption

\begin{tabular}{ll}
\hline & Model 14 \\
\hline Populism Score & 0.115 \\
& $(0.051)^{* *}$ \\
Population (ln) & 0.046 \\
& $(0.025)^{*}$ \\
GDP per capita (ln) & 0.402 \\
& $(0.051)^{* * *}$ \\
State Capacity & -0.097 \\
& $(0.073)$ \\
Unemployment $($ ln $)$ & 0.156 \\
& $(0.038)^{* * *}$ \\
Manufacturing & -0.001 \\
& $(0.007)$ \\
Fossil Fuel Consumption & 0.014 \\
& $(0.003)^{* * *}$ \\
Globalization & 0.033 \\
Democracy & $(0.008)^{* * *}$ \\
Constant & -0.025 \\
& $(0.012)^{* *}$ \\
& -5.920
\end{tabular}




\begin{tabular}{lc} 
& $(0.604)^{* * *}$ \\
\hline$N$ & 193 \\
Random Intercept & Yes \\
Time Fixed Effects & Yes \\
\hline
\end{tabular}

Note: Standard errors clustered on leaders in parentheses; * significant at $10 \%$; ** significant at $5 \%$; *** significant at $1 \%$ (two-tailed).

\section{References}

Anderson, Brilé, Tobias Böhmelt, and Hugh Ward. 2017. Public Opinion and Environmental Policy Output: A Cross-National Analysis of Energy Policies in Europe. Environmental Research Letters 12 (11): 114011.

Böhmelt, Tobias, Farzad Vaziri, and Hugh Ward. 2018. Does Green Taxation Drive Countries Towards the Carbon Efficiency Frontier? Journal of Public Policy 38 (4): 481-509.

Carter, Neil. 2013. Greening the Mainstream: Party Politics and the Environment. Environmental Politics 22 (1): 73-94.

Döring, Holger, and Philip Manow. 2012. Parliament and Government Composition Database (ParlGov): An Infrastructure for Empirical Information on Parties, Elections, and Governments in Modern Democracies. Available online: http://parlgov.org/.

Fredriksson, Per G., and Noel Gaston. 2000. Ratification of the 1992 Climate Change Convention: What Determines Legislative Delay? Public Choice 104 (3-4): 345-368.

Henisz, Witold J. 2000. The Institutional Environment for Economic Growth. Economics \& Politics 12 (1): 1-31.

Lin, David, Laurel Hanscom, Jon Martindill, Michael Borucke, Lea Cohen, Alessandro Galli, Elias Lazarus, Golnar Zokai, Katsunori Iha, and Mathis Wackernagel. 2019. Working Guidebook to the National Footprint and Biocapacity Accounts. Oakland: Global Footprint Network.

Van Der Heijden, Hein-Anton. 2002. Political Parties and NGOs in Global Environmental Politics. International Political Science Review 23 (2): 187-201.

Wiedmann, Thomas, Jan Minx, John Barrett, and Mathis Wackernagel. 2006. Allocating Ecological Footprints to Final Consumption Categories with Input-Output Analysis. Ecological Economics 56 (1): 28-48. 